\title{
Diagnostic algorithms in autoimmune encephalitis
}

\author{
Valentina Damato \\ Institute of Neurology, Catholic University of Sacred Heart, 00168 Rome, Italy.
}

\section{A B S T R A C T}

Over the past decade the discovery of novel forms of encephalitis associated with neuronal surface antibodies had changed the paradigms for diagnosing and treating disorders that were previously mischaracterized. Recognition of clinical syndromes, consistent methods of diagnosis, and early targeted immunotherapy can lead to a favorable outcome in diseases that may be associated with significant disability or death if left untreated. Here the conditions associated with neuronal surface antibodies are briefly reviewed, some general aspects of these syndromes are considered and guidelines that could help in the recognition of these disorders are suggested. Furthermore, a diagnostic algorithm to detect and characterize neuronal cell surface autoantibodies is suggested and some of the caveats of serum testing are outlined. Future directions will involve the identification of novel autoantibodies, the standardization of methods to detect and characterize them, as well as evaluation of the most efficacious therapeutic strategies in patients with established diagnosis of autoimmune encephalitis.

Key words: Autoimmune encephalitis; neuronal surface autoantibodies; paraneoplastic syndromes

\section{INTRODUCTION}

Anti-neuronal autoimmune encephalitis (AIE) is a complex syndrome resulting from a self-directed response to neuronal antigens. These disorders can be associated with immunoglobulinG (IgG) autoantibodies specific to intracellular neuronal antigens (e.g. Hu, Yo, Ri) and to neuronal surface or synaptic antigens [e.g. N-methyl-daspartate receptor (NMDAR), amino-3-hydroxy-5-hydroxy5-methyl-4-isoxazolepropionic acid receptor (AMPAR), gamma-aminobutyric acid B GABA(B)R]. The first group of AIE typically occurs in the setting of cancer, resulting from an autoimmune reaction against intracellular antigens coexpressed by the cancer and the central nervous system (CNS). The autoantibodies are thought to be not pathogenic but an epiphenomenon, and patients show limited or no response to immunotherapy. Compelling evidence suggests that in the second group of AIE, the binding of the autoantibodies to extracellular antigens directly causes neuronal dysfunction, which can be reversed by antibody-depleting therapies, ${ }^{[1]}$ such as plasmapheresis and intravenous immunoglobulins. In contrast to classical paraneoplastic syndromes, AIE associated with synaptic

Corresponding Author: Dr. Valentina Damato, Institute of Neurology, Catholic University of Sacred Heart, Largo F. Vito 1, 00168 Roma, Italy. E-mail: valentina.damato86@gmail.com

\begin{tabular}{|l|l|}
\hline \multicolumn{2}{|c|}{ Access this article online } \\
\hline Quick Response Code: & Website: \\
\hline & http://nnjournal.net \\
\cline { 2 - 3 } & \\
\hline
\end{tabular}

autoantibodies is often not paraneoplastic and can affect patients of all ages, including children and young adults. ${ }^{[2]}$

Over the past ten years, the characterization of encephalitis associated with neuronal surface autoantibodies has changed our perspective on their diagnosis and treatment. In these disorders, the autoantibodies are associated with a characteristic phenotype and their detection contributes to the neurological diagnosis. As early treatment speeds recovery, reduces disability and decreases relapses, it is important that the immune pathogenesis of these disorders is promptly recognized.

In this paper a diagnostical gorithm is proposed for a clinical approach to AIE and screening of the associated autoantibodies.

\section{DIAGNOSTIC APPROACH}

The diagnosis of AIE should be suspected in patients developing subacute cognitive impairment, psychiatric disturbances, movement disorders or seizures. The diagnosis will be further support by the evidence of CNS inflammation from cerebrospinal fluid (CSF) analysis or magnetic resonance imaging (MRI). Autoantibody testing has a critical role in confirming the diagnosis and in leading

This is an open access article distributed under the terms of the Creative Commons Attribution-NonCommercial-ShareAlike 3.0 License, which allows others to remix, tweak, and build upon the work non-commercially, as long as the author is credited and the new creations are licensed under the identical terms.

For reprints contact: service@oaepublish.com

How to cite this article: Damato V. Diagnostic algorithms in autoimmune encephalitis. Neuroimmunol Neuroinflammation 2016;3;93-7.

Received: 03-10-2015; Accepted: 25-12-2015 
the search for the presence of an underlying neoplasm [Figure 1].

\section{Clinical presentation}

AIE is usually a multistage process. Most of these disorders have a rapid course, developing over a few days or weeks, with behavioral and memory alteration, decreased level of consciousness and seizures. This clinical picture is typical of limbic encephalitis (LE). However, the severity and predominance of some symptoms over others may help the clinician in the diagnosis of different AIE subtypes and may lead the search for specific antibodies [Table 1]. For example, both GABA(B)R and gamma-aminobutyric acid A [GABA(A) $\mathrm{R}]$ antibodies are typically associated with refractory seizures, ${ }^{[4,5]}$ patients with leucine-rich glioma-inactivated 1 (LGI1) autoantibodies can present with facio-brachial dystonic seizuresand hyponatremia caused by syndrome of inappropriateantidiuresis (SIAD), ${ }^{[6]}$ while AMPAR-antibodies are frequently found in patients with LE or psychosis. ${ }^{[7]}$ In anti-NMDAR encephalitis, psychiatric disturbances are the most frequent symptoms of onset in women, ${ }^{[8]}$ while seizures are prominent in men. ${ }^{[9]}$

The detection and characterization of IgLON family member 5 antibodies represents an interesting link between autoimmunity and neurodegeneration. These autoantibodies were found to be associated with sleep disturbances, cognitive impairment, the movement disorder and brainstem symptoms with a chronic progressive course. ${ }^{[10]}$

In some cases, symptoms may extend beyond CNS: AIE associated with autoantibodies to dipeptidyl-peptidase-like protein-6 may present with diarrhea poorly responsive to symptomatic treatment and significant weight loss that can precede neurological symptoms including brainstem and

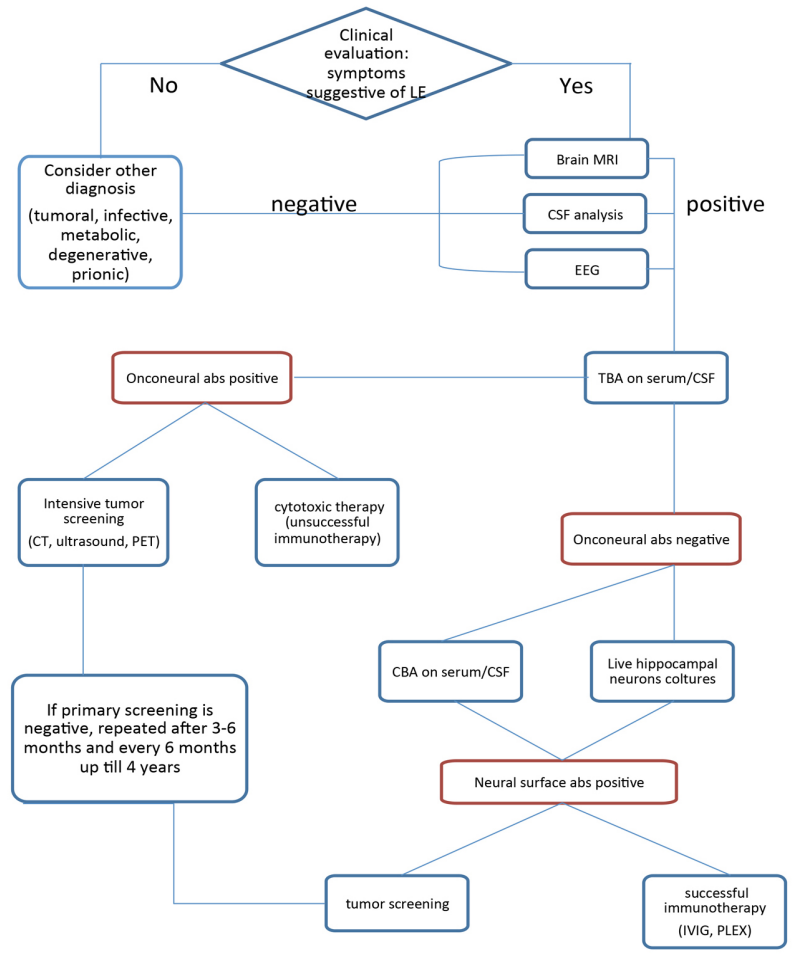

Figure 1: Flowchart summarizing a preferred diagnostic approach to AIE. AIE: Anti-neuronal autoimmune encephalitis; CSF: cerebrospinal fluid; CBA: cellbased assay; EEG: electroencephalogram; TBA: tissue-based assays; CT: computed tomography; PET: positron emission tomography; MRI: magnetic resonance imaging; IVIG: intravenous immunoglobulin; PLEX: plasmapheresis

psychiatric dysfunction. ${ }^{[1]}$

\section{Ancillary tests}

At presentation, about $80 \%$ of patients with AIE have a mildto-moderate CSF lymphocytic pleocytosis (usually $<100$ white blood cells/L), 30\% have a mild-to-moderate increase inprotein concentration, and 50-60\% have oligoclonal bands. $^{[12]}$ In contrast to most autoimmune encephalitides, encephalitis with LGI1-IgGusually occurs with normal or

\begin{tabular}{|c|c|c|c|}
\hline Antigen & Tumor & Clinical symptoms & Clinical clues \\
\hline NMDAR & $\begin{array}{l}\text { Ovarian teratoma }(58 \%) \\
<18 \text { years old }\end{array}$ & $\begin{array}{l}\text { Memory impairment, psychosis (mainly } \\
\text { in women), seizures (mainly in men), } \\
\text { central hypoventilation }\end{array}$ & Orobuccal dyskinesia; dysautonomia \\
\hline LGI1 & Thymoma $(<10 \%)$ & LE & $\begin{array}{l}\text { Hyponatremia; faciobrachial dystonic } \\
\text { seizures }\end{array}$ \\
\hline CASPR2 & Thymoma (38\%) & $\begin{array}{l}\text { Encephalitis/Morvansynd/ } \\
\text { neuromyotonia }\end{array}$ & $\begin{array}{l}\text { Peripheral nerve hyperexcitability; } \\
\text { neuropathic pain }\end{array}$ \\
\hline AMPAR & SCLC, breast, thymoma (60-70\%) & LE, psychosis & \\
\hline GABA(B) $R$ & $\operatorname{SCLC}(50 \%)$ & LE, ataxia & Refractory seizures \\
\hline $\operatorname{GABA}(\mathrm{A}) \mathrm{R}$ & - & Status epilepticus, seizures, LE & Refractory seizures \\
\hline mGluR1 & $\begin{array}{l}\text { Hodgkin and non Hodgkin lymphoma } \\
\text { (e.g. cutaneus lymphoma); prostate } \\
\text { adenocarcinoma }^{[3]}\end{array}$ & Cerebell arataxia & \\
\hline mGluR5 & M. Hodgkin & Ophelia syndrome & Memory impairment \\
\hline DPPX (Kv4.1) & Follicular B cell, lymphoma, CLL & $\begin{array}{l}\text { Hallucinations, agitation, myoclonus, } \\
\text { tremor, SPS }\end{array}$ & Diarrhea \\
\hline IgLON5 & - & Brain stem dysfunction, LE & Non-REM and REM-sleep disorder \\
\hline GlyR & Thymoma & SPS, progressive encephalitis & \\
\hline Dopamine 2R & - & $\begin{array}{l}\text { Basal ganglia encephalitis, Sydenham } \\
\text { Chorea }\end{array}$ & \\
\hline
\end{tabular}

NMDAR: N-methyl-d-aspartate receptor; LGI1: leucine-rich glioma-inactivated 1; CASPR2:contactin-associated protein-like 2; AMPAR: amino-3-hydroxy-5-hydroxy-5-methyl4-isoxazolepropionic acid receptor; GABA A/B R: gamma-aminobutyric acid A/B receptor; mGluR1/5: metabotropic glutamate receptor type 1/5; DPPX: dipeptidyl-peptidaselike protein-6; GlyR: Glycine receptor; CLL: chronic lymphatic leukemia; SCLC: small cell lung cancer; LE: limbic encephalitis; SPS: stiff-person syndrome; IgLON5: IgLON family member 5 
minimal CSF findings. ${ }^{[13]}$

The electroencephalogram (EEG) is almost always abnormal in all types of AIE, showing focal or diffuse slow activity that can be associated with focal or multifocal epileptic discharges. Except for a pattern referred to as extreme delta brush, that may occur in patients with anti-NMDAR encephalitis, ${ }^{[14]}$ there are no pathognomonic EEG abnormalities for any AIE subtypes.

MRI of the brain is often diagnostic in patients with LE, usually showing increased Fluid Attenuated Inversion Recovery/T2-weighted (FLAIR/T2) signal involving one or both temporal lobes, without contrast enhancement. Similar findings can, however, occur in patients with herpes simplex encephalitis or medial temporal lobe seizures. In NMDAR encephalitis brain MRI is normal in up to $66 \%$ of cases, while the remaining patients may have unspecific cortical or subcortical FLAIR/T2 abnormalities, sometimes involving the posterior fossa or medial temporal regions, often with small areas of demyelination, and more rarely with extensive demyelinating abnormalities. ${ }^{[15]}$

In patients with $\mathrm{GABA}(\mathrm{A}) \mathrm{R}$ antibodies, brain MRI often shows multifocal cortical-subcortical FLAIR abnormalities. ${ }^{[16]}$

\section{Detection of autoantibodies}

Several techniques are available for intracellular and synaptic antibody detection, for example, tissue-based assays (TBA; in-house or commercially available), cell-based assay (CBA; in-house or commercially available), indirect immunofluorescence on live hippocampal or cortical neurons (in-house) and immunoprecipitation (IP; in-house). In TBA, antibodies in patient serum or CSF are detected by indirect immunofluorescence on a substrate of mouse or rat brain sections. TBA is an excellent screening method, as the antibody target antigen can be suspected from the staining pattern (e.g. neuropil), although it must be confirmed by more specific techniques [Figure 2A]. As regards the detection of onconeural antibodies (e.g. Hu, Ma2, Ri, amphiphysin), commercial immunoblots with recombinant proteins for the most common autoantibodies are widely available. On the other hand, the gold standard for neuronal surface autoantibody detection is CBA, in which cells (e.g. human embryonic kidney 293 cells) expressing the appropriate antigens are incubated with patients' serum/CSF, and antibodies are identified by indirect immunofluorescence [Figure 2C]. This is a highly sensitive technique, but it is time consuming and requires specific facilities and expertise.

Indirect immunofluorescence on live hippocampal or cortical murine neurons is used as a screening method, in some laboratories, for the detection of antibodies binding neuronal plasma membrane proteins [Figure 2B].

The most reliable method of detecting antibodies specific for neuronal plasma membrane antigens involves using a combination of TBA and indirect immunofluorescence on live neuronal cultures as screening following by confirmatory CBA.

\section{Caveats in the diagnosis}

Standardized methods of antibody testing are critical to ensure the correct diagnosis of AIE. However there are few studies, mainly in anti-NMDAR encephalitis, ${ }^{[17-19]}$ comparing the sensitivity and specificity of different techniques in serum and CSF samples from patients with AIE. For example, Gresa-Arribas et al. ${ }^{[20]}$ examined paired serum

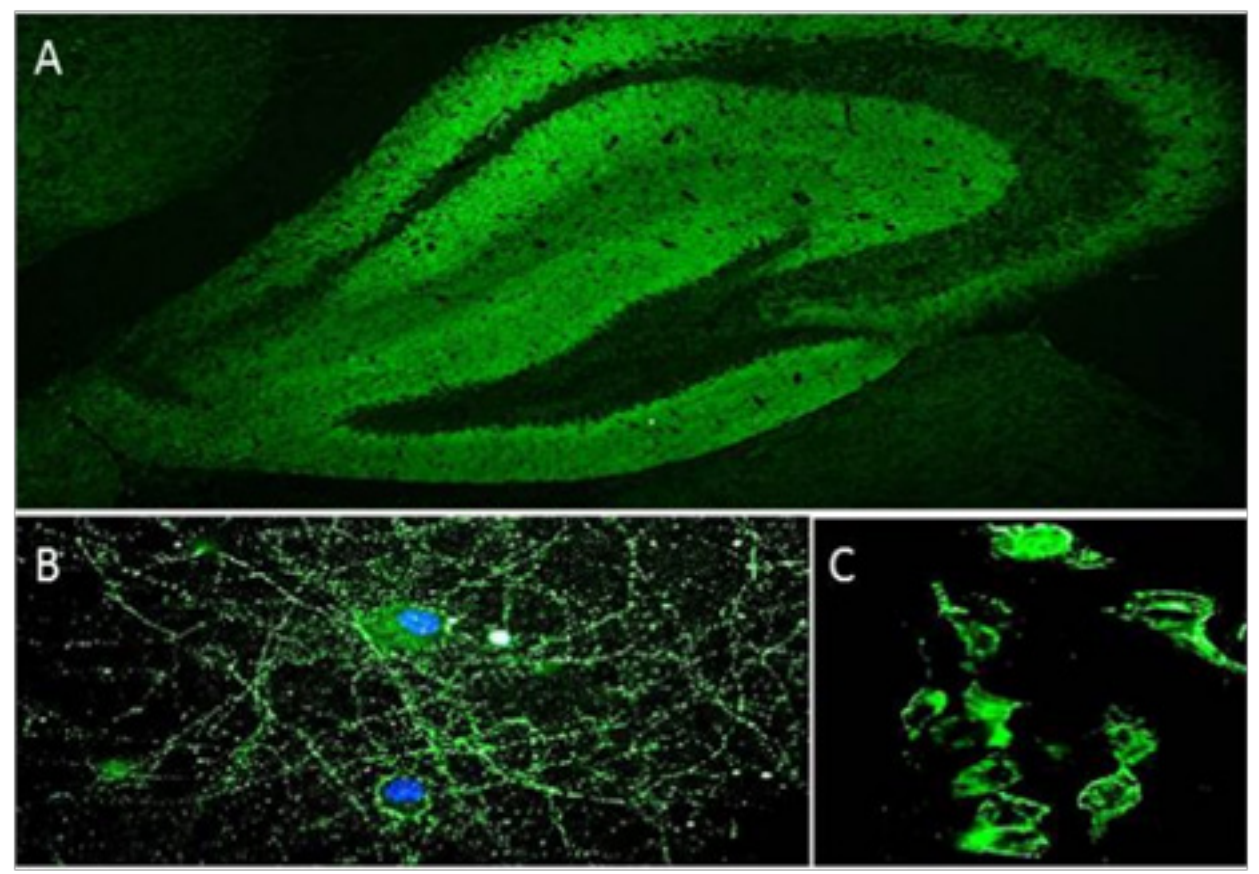

Figure 2: IgG in the CSF from a patient with anti-NMDAR encephalitis bind to the neuropil of the mouse hippocampus (A), to the cell-surface of live, nonpermeabilized mouse hippocampal neurons (B) and to the plasma membrane of HEK293 cells expressing NMDAR (C). anti-NMDAR: anti-N-methyl-d-aspartate receptor 
and CSF from 250 patients with anti-NMDAR encephalitis and 100 controls tested with three different assays showing that, while autoantibodies are always detected in CSF, serum testing with any type of cell-based assay (live or fixed cells) led to false negative results in at least 13\% of the patients. Similarly, in another study, ${ }^{[21]} 23 \%$ of patients with anti-NMDAR encephalitis tested negative when only serum samples were evaluated by live CBA. Moreover, Dahm et $a l^{[22]}$ recently reported that approximately $10 \%$ of patients with diverse neuropsychiatric disorders and healthy individuals may have IgA, IgM or IgG autoantibodies to the NR1 subunit of the NMDAR in the peripheral blood. However they found a prevalence of IgA and IgM at low titer, whose detection has no utility for diagnosing NMDAR encephalitis. Using commercial tests, IgA, IgM and IgG anti-NMDAR autoantibodies, at low titer, showed a broader distribution and can be detected in the serum of a considerable percentage of healthy subjects. ${ }^{[2]}$ These data suggest that CSF anti-NMDAR autoantibody titers show a much better correlation with clinical symptoms than blood autoantibody titers. In contrast, LGI1-antibodies seem to be more prevalent in serum, although most patients have also CSF autoantibodies. ${ }^{[13]}$

In general, these findings suggest that multicenter studies are needed to determine the sensitivity and specificity of the different methods of autoantibody detection. To minimize errors of interpretation and misleading diagnoses, in all suspected cases of AIE both serum and CSF should always be tested for autoantibodies.

\section{Tumor screening}

CNS dysfunction sometimes reflects an effective immune response to an underlying neoplasm. Paraneoplastic neurological disorders should be suspected when the onset is subacute, with rapid progression not explained by more common disorders. Neurological symptoms generally precede the diagnosis of cancer that may remain unsuspected and undetectable both clinically and by conventional radiology for long after neurological symptom onset. $^{[24]}$

Although certain neural-specific autoantibodies frequently associate with distinctive neurological presentations, none of the antibodies is specific for a unique syndrome. Autoantibodies that are highly predictive of cancer, however, are tightly associated with a limited number of tumors that express the antibody-target antigen [Table 1]. Therapeutic intervention in these cases consists of searching for and treating the associated tumor in order to eliminate the diseasetriggering stimulus. ${ }^{[25]}$ In addition, the detection of onconeural or neuronal surface antibodies is crucial in the diagnosis of an immune condition, thus in the therapeutic decisions [Figure 1]. In the case of onconeural antibody positivity, the neuronal tissue damage is thought to be initially mediated by T-cells and consequently, an immunosuppressive therapy does not usually improve the clinical symptoms. If, in contrast, cell surface structures are the target of the humoral reaction, early immunosuppression, if applicable, tumor resection is indicated. In these cases substantial recovery is possible. ${ }^{[26]}$ The European Federation of Neurological Societies developed a useful guideline regarding tumor screening in AIE. ${ }^{[27]}$ For screening of the thoracic region, a computed tomography (CT)-thorax is recommended, which if negative is followed by fluorodeoxyglucose-positron emission tomography. Breast cancer is screened for using mammography, followed by MRI. For possible pelvic and gastrointestinal malignancies, ultrasound scanning (US) of the pelvic region followed by CT is recommended in women (especially for ovarian teratoma), while US of the testes should be considered in men under 50 years of age, and colonoscopy in both men and women over 50. If primary screening is negative, it should be repeated after 3-6 months and then every 6 months up till 4 years.

\section{CONCLUSION}

Ongoing research on AIE constantly increases the number of novel autoantibodies and expands the spectrum of neurological syndromes, which is crucial in the differential diagnosis. Identification of the specific AIE is important in the complex management of these patients as these disorders may have different co-morbidities or associated tumors. Moreover, the discovery of new AIE has led to unsuspected links with other CNS diseases (e.g. antiepileptic-drug-resistant epilepsy, relapsing encephalitis post-HSV, demyelinating disease) making the diagnosis an interdisciplinary challenge for the treating physicians. ${ }^{[28-30]}$

Given the abundance of antibodies that have been reported so far, physicians face the dilemma of which antibody to test first, especially if TBA gives inconsistent results. In terms of priority, it is important to consider first NMDAR and voltagegated potassium channel (VGKC-complex) which comprises LGI1 and contactin-associated protein-like 2 autoantibodies, because they are the most frequent antibodies associated with AIE.

The clinical spectrum of autoimmune encephalitis is broad, but prompt recognition and treatment often leads to excellent outcome. Yet, despite being a potentially reversible neurological condition, no clear guidelines for diagnosis and treatment of AIE exist.

Prospective population-based studies to evaluate the impact of different immunotherapies in AIE as well as to standardize the different diagnostic tests are needed in order to improve the management of these complex disorders.

\section{Acknowledgments}

The author thanks Prof. Amelia Evoliand Dr. Paolo Alboini for their critical revisions of the manuscript and the flowchart. A 
special thanks to Dr. Raffaele Iorio for providing the pictures included in Figure 2.

\section{Financial support and sponsorship}

Nil.

\section{Conflicts of interest}

There are no conflicts of interest.

\section{REFERENCES}

1. Iorio R, Lennon VA. Neuralantigen-specific autoimmune disorders. Immunol Rev 2012;248:104-21.

2. Armangue T, Petit-Pedrol M, Dalmau J. Autoimmune encephalitis in children. JChild Neurol 2012;27:1460-9.

3. Iorio R, Damato V, Mirabella M, Vita MG, Hulsenboom E, Plantone D, Bizzarro A, Del Grande A, Sillevis Smitt PA. Cerebellar degeneration associated with mGluR1 autoantibodies as a paraneoplastic manifestation of prostate adenocarcinoma. JNeuroimmunol 2013;263:155-8.

4. Lancaster E, Lai M, Peng X, Hughes E, Constantinescu R, Raizer J, Friedman D, Skeen MB, Grisold W, Kimura A, Ohta K, lizuka T, Guzman M, Graus F, Moss SJ, Balice-Gordon R, Dalmau J. Antibodies to the GABA(B) receptor in limbic encephalitis with seizures: case series and characterization of the antigen. Lancet Neurol 2010;9:67-76.

5. Ohkawa T, Satake S, Yokoi N, Miyazaki Y, Ohshita T, Sobue G, Takashima $\mathrm{H}$, Watanabe O, Fukata Y, Fukata M. Identification and characterization of GABA(A) receptor autoantibodies in autoimmune encephalitis. J Neurosci 2014:34:8151-63.

6. Lai M, Huijbers M.G, Lancaster E, Graus F, Bataller L, Balice-Gordon $\mathrm{R}$, Cowell JK, Dalmau J. Investigation of LGI1 as the antigen in limbic encephalitis previously attributed to potassium channels: a case series. Lancet Neurol 2010;9:776-85.

7. Panzer JA, Dale RC. Anti-AMPA receptor encephalitis: the family of glutamatergic autoencephalitides further expands. Neurology 2015;84:2390-1.

8. Kuppuswamy PS, Takala CR, Sola CL. Management of psychiatric symptoms in anti-NMDAR encephalitis: a case series, literature review and future directions. Gen Hosp Psychiatry 2014;36:388-91.

9. Titulaer MJ, Dalmau J. Seizures as first symptom of anti-NMDA receptor encephalitis are more common in men. Neurology 2014;82:550-1.

10. Sabater L, Gaig C, Gelpi E, Bataller L, Lewerenz J, Torres-Vega E, Contreras A, Giometto B, Compta Y, Embid C, Vilaseca I, Iranzo A, Santamaría J, Dalmau J, Graus F. A novel non-rapid-eye movement and rapid-eye-movement parasomnia with sleep breathing disorder associated with antibodies to IgLON5: a case series, characterization of the antigen, and post-mortem study. Lancet Neurol 2014;13:575-86.

11. Boronat A, Gelfand JM, Gresa-Arribas N, Jeong HY, Walsh M, Roberts K Martinez-Hernandez E, Rosenfeld MR, Balice-Gordon R, Graus F, Rudy B, Dalmau J. Encephalitis and antibodies to dipeptidyl-peptidase-like protein-6, a subunit of Kv4.2 potassium channels. Ann Neurol 2013;73:1208.

12. Malter MP, Elger CE, Surges R. Diagnostic value of CSF findings in antibodyassociated limbic and anti-NMDAR-encephalitis. Seizure 2013;22:136-40.

13. Jarius S, Hoffmann L, Clover L, Vincent A, Voltz R. CSF findings in patients with voltagegated potassium channel antibody associated limbic encephalitis. JNeurol Sci 2008;268:74-7.

14. Schmitt SE, Pargeon K, Frechette ES, Hirsch LJ, Dalmau J, Friedman D. Extreme delta brush: a unique EEG pattern in adults with anti-NMDA receptor encephalitis. Neurology 2012;79:1094-100.

15. Armangue T, LeypoldtF, Dalmau J. Autoimmune encephalitis as differential diagnosis of infectious encephalitis. Curr Opin Neurol 2014;27:361-8.
16. Petit-Pedrol M, Armangue T, Peng X, Bataller L, Cellucci T, Davis R, McCracken L, Martinez-Hernandez E, Mason WP, Kruer MC, Ritacco DG, Grisold W, Meaney BF, AlcaláC, Sillevis-Smitt P, Titulaer MJ, BaliceGordon R, Graus F, Dalmau J. Encephalitis with refractory seizures, status epilepticus, and antibodies to the GABAA receptor: a case series, characterization of the antigen, and analysis of the effects of antibodies. Lancet Neurol 2014;13:276-86.

17. Dalmau J, Gleichman AJ, Hughes EG, Rossi JE, Peng X, Lai M, Dessain SK, Rosenfeld MR, Balice-Gordon R, Lynch DR. Anti-NMDA-receptor encephalitis: case series and analysis of the effects of antibodies. Lancet Neurol 2008;7:1091-8.

18. Titulaer MJ, McCracken L, Gabilondo I, Armangué T, Glaser C, lizuka T, Honig LS, Benseler SM, Kawachi I, Martinez-Hernandez E, Aguilar E, Gresa-ArribasN, Ryan-Florance N, Torrents A, Saiz A, Rosenfeld MR, Balice-Gordon R, Graus F, Dalmau J. Treatment and prognostic factors for long-term outcome in patients with anti-NMDA receptor encephalitis: an observational cohort study. Lancet Neurol 2013;12:157-65.

19. Viaccoz A, Desestret V, Ducray F, Picard G, Cavillon G, Rogemond $\mathrm{V}$, Antoine JC, Delattre JY, Honnorat J. Clinical specificities of adult male patients with NMDA receptor antibodies encephalitis. Neurology 2014:82:556-63.

20. Gresa-Arribas N, Titulaer MJ, Torrents A, Aguilar E, McCracken L, Leypoldt F, Gleichman AJ, Balice-Gordon R, Rosenfeld MR, Lynch D, GrausF, Dalmau J. Antibody titers at diagnosis and during follow-up of anti-NMDA receptor encephalitis: a retrospective study. Lancet Neurol 2014;13:167-77.

21. Zandi MS, Paterson RW, Ellul MA, Jacobson L, Al-Diwani A, Jones JL, Cox AL, Lennox B, Stamelou M, Bhatia KP, Schott JM, Coles AJ, Kullmann DM, Vincent A. Clinical relevance of serum antibodies to extracellular N-methylaspartate receptor epitopes. JNeurol Neurosurg Psychiatry 2015;86:708-13.

22. Dahm L, Ott C, Steiner J,Stepniak B, Teegen B, Saschenbrecker S, Hammer C, Borowski K, Begemann M, Lemke S, Rentzsch K, Probst C, Martens H, Wienands J, Spalletta G, Weissenborn K, Stöcker W, Enrenreich $\mathrm{H}$. Seroprevalence of autoantibodies against brain antigens in health and disease. Ann Neurol 2014;76:82-94.

23. Steiner J, Teegen B, Schiltz K, Bernstein HG, Stoecker W, Bogerts B. Prevalence of $\mathrm{N}$-methyl-D-aspartate receptor autoantibodies in the peripheral blood: healthy control samples revisited. JAMA Psychiatry 2014:71:838-9.

24. McKeon A, Pittock SJ. Paraneoplastic encephalomyelopathies: pathology and mechanisms. Acta Neuropathol 2011;122:381-400.

25. Graus F, Dalmau J. Paraneoplastic neurological syndromes. Curr Opin Neurol 2012;25:795-801.

26. Lancaster E, Dalmau J. Neuronal autoantigens-pathogenesis, associated disorders and antibody testing. Nat Rev Neurol 2012;8:380-90.

27. Titulaer MJ, Soffietti R, Dalmau J, Gilhus NE, Giometto B, Graus F, Grisold W, Honnorat J, Sillevis Smitt PA, Tanasescu R, Vedeler CA, Voltz R, Verschuuren JJ. European Federation of Neurological Societies. Screening for tumours in paraneoplastic syndromes: report of an EFNS task force. Eur JNeurol 2011;18:19-e3.

28. Iorio R, Assenza G, Tombini M, Colicchio G, Della Marca G, Benvenga A, Damato V, Rossini PM, Vollono C, Plantone D, Marti A, Batocchi AP, Evoli A. The detection of neural autoantibodies in patients with antiepilepticdrug-resistant epilepsy predicts response to immunotherapy. Eur J Neurol 2015;22:70-8.

29. Armangue T, Leypoldt F, Malaga I, Raspall-Chaure M, Marti I, Nichter C, Pugh J, Vicente-Rasoamalala M, Lafuente-Hidalgo M, Macaya A, Ke M, Titulaer MJ, Höftberger R, Sheriff H, Glaser C, Dalmau J. Herpes simplex virus encephalitis is a trigger of brain autoimmunity. Ann Neurol 2014:75:317-23.

30. Titulaer MJ, Hoftberger R, lizuka T, Leypoldt F, McCracken L, Cellucci T, Benson LA, Shu H, Irioka T, Hirano M, Singh G, CoboCalvo A, Kaida K, Morales PS, Wirtz PW, Yamamoto T, Reindl M, Rosenfeld MR, GrausF, Saiz A, Dalmau J. Overlapping demyelinating syndromes and anti-N-methyl-Daspartate receptor encephalitis. Ann Neurol 2014;75:411-28. 